\title{
Outcomes of septic shock due to multidrug resistant bacteraemia treated with phosphomycine
}

\author{
A Theohari', E Koutsioumpa, E Manoulakas, K Mantzarlis, D Makris, E Zakynthinos \\ From ESICM LIVES 2015 \\ Berlin, Germany. 3-7 October 2015
}

\section{Introduction}

The management of septic shock due to gram negative infections is challenging due to the multidrug antibiotic resistance of some bacterial species.

\section{Objectives}

We investigated outcomes of critical care patients with septic shock due to gram negative bacteraimia susceptible only to phosphomycine.

\section{Methods}

Data from septic shock cases hospitalized in a tertiary ICU, during 2014, were retrospectively collected if patients had received phosphomycine i.v. at least for seventy-two hours, as rescue therapy for septic shock bacteraemia due to multidrug resistant (including colistin resistance) bacteria. Main outcomes (i.e. death in ICU, recovery from septic shock) were compared with cases of septic shock due to multidrug resistant (but susceptible at least to colistin) gram negative bacteraemia (first ICU episode) who received appropriate antibiotic therapy for at least seventytwo hours (Controls).

\section{Results}

Twelve Cases and 14 Controls were included in the study. Median(IQR) age (years) were 56(45.5-69.2) and 62(5765), APACHE II 21(20-31) and 18(14-24.5), ICU day of septic shock 63.5(39.5-129.7) and 10(5-16). Duration (days) of phosphomycine treatment was 12.5(9.7-15). Initial empirical antibiotic therapy was appropriate in $62.5 \%$ of Controls. Four (33\%) Case and 9 (64\%) Controls recovered from septic shock in both groups $(\mathrm{p}=0.23)$. ICU duration in Cases and Controls were 73(41-152) and 25(16-33) ( $\mathrm{p}=0.02)$ while overall mortality was $75 \%$ and $67 \%$ respectively $(\mathrm{p}>0.5)$.

University Hospital of Larisa, ICU, Larisa, Greece

\section{Conclusions}

The use of phosphomycine as rescue therapy in septic shock due to multidrug resistant bacteraemia resulted in low recovery rates although not significantly different compared to patients with septic shock due to multidrug resistant (susceptible to more than two antibiotics including colistin) bacteria.

Published: 1 October 2015

doi:10.1186/2197-425X-3-S1-A87

Cite this article as: Theohari et al:: Outcomes of septic shock due to multidrug resistant bacteraemia treated with phosphomycine. Intensive Care Medicine Experimental 2015 3(Suppl 1):A87.

\section{SpringerOpen $^{\odot}$}

(0) 2015 Theohari et al.; This is an Open Access article distributed under the terms of the Creative Commons Attribution License (http:// creativecommons.org/licenses/by/4.0), which permits unrestricted use, distribution, and reproduction in any medium, provided the original work is properly cited.
Submit your manuscript to a SpringerOpen ${ }^{\circ}$ journal and benefit from:

- Convenient online submission

- Rigorous peer review

- Immediate publication on acceptance

- Open access: articles freely available online

- High visibility within the field

Retaining the copyright to your article

Submit your next manuscript at $>$ springeropen.com 